\title{
POLITIK HUKUM PERLINDUNGAN KOMODITAS TANAMAN PANGAN DALAM NEGERI
}

\author{
Eri Hendro Kusuma \\ Universitas Kahuripan Kediri \\ Jl. Soekarno Hatta No. 1 Pare Kediri \\ e-mail: erihendro@ymail.com
}

\begin{abstract}
Management of natural resources in accordance with the principle of "people's economy" that characterizes a democracy based on the values of Pancasila, has not been completely worked well. Currently $85 \%$ of all products horticulture outstanding and enjoyed by consumers in Indonesia are imported. Politics law on food in Indonesia appears to have far into the liberal economic level. This will directly impact on national food crisis. The state has a duty to achieve food sovereignty in the country. The state can carry out their vital role in suppressing or minimizing the goods imported into the territory of Indonesia for the realization of food sovereignty.
\end{abstract}

Keyword: politics law, products horticultural

\begin{abstract}
Abstrak: Pengelolaan sumber daya alam yang sesuai dengan prinsip "ekonomi kerakyatan” yang menjadi ciri khas demokrasi berdasarkan nilai-nilai Pancasila, belum sepenuhnya berjalan dengan baik. Saat ini $85 \%$ dari seluruh produk Hortikultura yang beredar dan dinikmati oleh konsumen di Indonesia merupakan produk impor. Politik hukum tentang pangan di Indonesia nampaknya sudah jauh masuk kedalam tataran ekonomi liberal. Ini secara langsung akan berdampak pada krisis pangan nasional.Negara mempunyai kewajiban untuk mewujudkan kedaulatan pangan dalam negeri. Negara dapat melaksanakan peranan pentingnya dalam hal menekan atau meminimalisir suatu barang impor yang masuk ke wilayah Indonesia demi terwujudnya kedaulatan pangan.
\end{abstract}

Kata Kunci: politik hukum, tanaman pangan

Indonesia adalah negara kepulauan yang luas dengan jumlah pulau yang banyak dan lautan yang luas, serta jumlah penduduk yang besar dan budaya yang beranekaragam, sehingga pembangunan Indonesia memerlukan pendekatan kepulauan yang kekuatannya terbentuk dari kekuatan pembangunan maritim dan dirgantara. Semua kebijakan pembangunan Indonesia termasuk perlu disesuaikan dengan karakter suatu negara (Komite IV DPR RI, 2014:1).

Ungkapan dalam bahasa Jawa yang sering dilontarkan oleh orang-orang tentang negara Indonesia yaitu "bangsa Indonesia adalah bangsa yang gemah ripah loh jinawi (kekayaan alam yang berlimpah) sehingga sudah seharusnya menjadi bangsa yang toto tentrem kerto raharjo (menciptakan kesejahteraan dan keadaan yang aman tentram, dan damai bagi seluruh rakyat Indonesia) (Suhariningsih, 2014:477). Dalam sebuah lagu di era tahun tujuh puluhan yang diciptakan oleh grup band Koesplus juga menggambarkan potensi yang dimiliki oleh bangsa Indonesia, sebagian cuplikan bait lagu tersebut adalah "kata orang tanah kita tanah surga, tongkat kayu dan batu jadi tanaman". Dari cuplikan lagu yang dipopulerkan oleh salah satu band tersebut menggambarkan begitu luar biasanya kondisi alam di Indonesia sampai-sampai mengistilahkan bahwa tanah kita adalah tanah surga, apa yang ditanam di Indonesia bisa tumbuh dengan baik. Istilah tongkat kayu ini menggambarkan sebuah varietas tanaman ubi yang menjadi makanan favorit bangsa Indonesia.

Akan tetapi apa yang digambarkan keadaan bangsa Indonesia, baik berupa ungkapan dalam bahasa jawa maupun cuplikan bait lagu tersebut berbanding terbalik dengan realitas hari ini yang berkembang di dalam masyarakat. Menurut laporan dari Gabungan Importir Hasil Bumi Indonesia, impor produk hortikultura (buah dan sayur) yang dilakukan 
oleh Indonesia terhitung besar. Saat ini $85 \%$ dari seluruh produk Hortikultura yang beredar dan dinikmati oleh konsumen di Indonesia merupakan produk impor. Selain itu, jumlah impor produk tersebut selalu meningkat setiap tahunnya. Sebagai contoh, berdasarkan data dari Badan Pusat Statistik (BPS) impor buah Indonesia dari Cina (sebagai negara pemasok buah impor terbesar ke Indonesia sepanjang tahun 2011 dan periode Januari Februari 2012) mengalami kenaikan dari angka US $\$ 46,7$ juta pada bulan Desember 2011 menjadi US\$62,6 juta pada bulan Januari 2012 dan dari angka US $\$ 30$ juta pada bulan Februari menjadi US $\$ 48,2$ juta pada bulan Maret di tahun yang sama. Selain itu impor buah dari Thailand juga mengalami kenaikan dari angka US $\$ 10,95$ juta pada bulan Juni 2012 menjadi US $\$ 35,07$ juta pada bulan Juli 2012 dan mencapai angka US\$40,55 juta pada bulan Agustus 2012 (Nisa, 2012).

Kemudian yang menjadi permasalahan lagi adalah Impor Singkong yang sudah dilakukan oleh pemerintah Indonesia sejak tahun 2007 menambah deretan kelemahan produk dalam negeri kita. Indonesia mulai mengimpor singkong (dalam bentuk tepung) sejak 2007 lalu sebanyak 300 ribu ton, pada 2008 Indonesia mengimpor 160 ribu ton, pada 2009 impor 170 ribu ton, pada 2010 mengimpor 290 ribu ton, dan pada 2011 lalu Indonesia mengimpor sebanyak 435 ton (Kurniawan, 2012).

Pada April 2014, Indonesia melalui Badan Pusat Logistik (BPS) mengimpor beras sebesar 31.145 ton atau US\$13,5 juta. Angka impor beras terus meningkat pada Mei sebesar 34.796 ton atau US\$13,5 juta, dan Juni sebesar 49.539 ton atau US\$22,3 juta. Angka ini masih akan terus bertambah mengingat pada periode Juli hingga Agustus 2014, Indonesia mengimpor 500.000 ton beras dari Vietnam, dengan dana sebesar Rp 300 miliar.Pada semester awal tahun 2014, impor beras terbesar tercatat dari Thailand sebesar 90.763 ton atau US\$ 42,6 juta, disusul India 61.546 ton atau US\$22,3 juta, Pakistan 8.950 ton atau US\$ 3,33 juta. Vietnam berada di peringkat keempat dengan 6.206 ton atau US\$ 3,3 juta, dan Myanmar 8.136 ton atau US\$2,7 juta. Beberapa negara lainnya juga menjadi negara pengekspor beras ke Indonesia dengan kisaran sebesar 675 ton atau US\$ 1,9 juta (Sari, 2014).

Uraian di atas menunjukkan bahwa pengelolaan sumber daya alam yang sesuai dengan prinsip ekonomi kerakyatan yang menjadi ciri khas demokrasi berdasarkan nilai-nilai Pancasila belum sepenuhnya berjalan dengan baik. Pemerintah bisa membuat sebuah kebijakan agar lingkungan sumber daya pertanian dalam negeri tetap terjaga keberlanjutannya dengan merubah paradigma yang menguntungkan petani lokal dalam memenuhi kebutuhan pangan nasional. Kebijakan pemerintah tersebut haruslah sejalan dengan cita hukum bangsa Indonesia yaitu Pancasila khusunya sila kelima yaitu "Keadilan Sosial Bagi Seluruh Rakyat Indonesia". Disamping itu amanat UUD 1945 Pasal 28 A ayat 1 juga jelas menyatakan bahwa "setiap orang berhak hidup sejahtera lahir dan bathin, bertempat tinggal dan mendapatkan lingkungan hidup yang baik dan sehat serta berhak memperoleh pelayanan kesehatan" mengisayaratkan pentingnya kebutuhan pangan dalam mencapai kehidupan sejahtera lahir dan bathin.Kemudian secara operasional untuk memaknai kedaulatan pangan, ketahanan, dan keamanan pangan, Indonesia telah menerbitkan Undang-Undang Republik Indonesia No 18 tahun 2012 tentang pangan, menggantikan UndangUndang No 7 tahun 1996 tentang pangan.

Berdasarkan uraian rumusan latar belakang tersebut diatas, maka ada dua pertanyaan yang mendasar yang perlu dikaji dalam makalah ini yaitu: (1) bagaimana jaminan perlindungan hukum nasional terhadap tanaman komoditas pangan dalam negeri saat ini?, dan (2) bagaimana rekonstruksi politik hukum perlindungan tanaman komoditas pangan dalam negeri guna mewujudkan kedaulatan pangan nasional?

Permasalahan Pertama, tentang jaminan perlindungan hukum nasional terhadap tanaman komoditas pangan dalam negeri yang dianalisis dengan menggunakan teori perlindungan hukum dan teori pangan. Teori perlindungan hukum dibedakan menjadi dua, yaitu perlindungan hukum preventif yang bertujuan untuk mencegah terjadinya permasalahan dan yang kedua adalah perlindungan hukum yang represif yang bertujuan untuk menyelesaikan permasalahan yang timbul (Hadjon, 1987:205). Pada intinya perlindungan hukum merupakan harkat dan martabat dan pengakuan terhadap haka asasi manusia guna mencegah terjadinya kesewenang-wenangan. Teori pangan sebagai hak asasi manusia sangat penting dan mendasar untuk dijadikan dasar mengevaluasi kembali kewajiban negara dalam memenuhi hak-hak dasar warga negaranya, khususnya dibidang pemenuhan hak warga negara dan ketersediaan pangannya (Safa'at, 2011:35). 
Permasalahan kedua, tentang rekonstruksi politik hukum perlindungan tanaman komoditas pangan dalam negeri guna mewujudkan kedaulatan pangan nasional akan dianalisa dengan menggunakan teori politik hukum, teori progresif, dan teori perundang-undangan. Teori politik hukum menurut Mahfud MD (1998:1-12) yang menyatakan bahwa politik hukum membahas mengapa politik mengintervensi hukum, bagaiamana politik mempengaruhi hukum, sistem politik mempengaruhi hukum. Teori Hukum Progresif menurut Raharjo (2009:519)adalahhukum itu bukan hanya bangunan peraturan, melainkan juga bangunan ide, kultur, dan cita-cita". Teori perundang-undangan Jeremy Bentham (dalam Erwin, 2013:180-188) yang digunakan untuk menganalisis produk kebijakan dan perundang-undangan dibidang ketahanan pangan yang dalam menyusun peraturannya telah atau sudah sesuai dengan kemanfaatan (utilatiarianisme) sebagai peraturan yang baik. Rekonstruksi politik hukum dilakukan dengan menganalisa berbagai kelemahan dan penyimpangan serta keunggulan baik yang menyangkut perilaku maupun teks pengaturan yang terkait dengan ketahanan pangan terutama masalah perlindungan terhadap tanaman pangan komoditas dalam negeri mulai dari komponen substansi hukum, yang menyangkut isi peraturan perundang-undangan. Komponen struktural yang berkaitan dengan aparat pemrumus undangundang dan penegak hukum. Serta kultur yang berkaitan dengan tingkat kepatuhan masyarakat terhadap hukum yang berlaku (Safaat, 2011:40).

\section{JAMINAN PERLINDUNGAN HUKUM NASIONAL TERHADAP TANAMAN KOMODITAS PANGAN DALAM NEGERI}

Kaitannya dengan pemenuhan perlindungan hukum nasional terhadap komiditas pangan dalam negeri Indonesia memiliki dasar filosofis dan sumber hukum yang dapat dijadikan sebagai sebuah rujukan oleh penyelenggara negara dalam melindungi komoditas tanaman komoditas dalam negeri. Pancasila sebagai cita hukum nasional sudah menjadi sebuah kepastian sebagai dasar filosofisnya. Sedangkan sumber hukum nasional yang menerjemahkan dari nilai-nilai Pancasila tersebut adalah Undang-Undang Dasar Negara Republik Indonesia Tahun 1945. Diantara lima nilai yang ada di dalam Pancasila maka yang relevan dalam pembahasan makalah ini adalah nilai yang kelima yaitu "Keadilan Sosial Bagi Seluruh Rakyat Indonesia". Sila kelima ini kemudian di operasionalkan atau dijabarkan dalam bentuk teks hukum berupa pasal dan ayat yang ada di UUD 1945 khususnya Pasal 28 A ayat (1) dan Pasal 33 ayat (!) sampai dengan (4).

Memaknai kedaulatan pangan, ketahanan, dan keamanan pangan maka Indonesia telah menerbitkan Undang-Undang No 18 tahun 2012 tentang pangan, menggantikan Undang-Undang No 7 tahun 1996 tentang pangan. Istilah pangan dapat ditemukan pada Pasal 1 Undang-Undang No 18 tahun 2012 tentang pangan sebagai berikut, 1. Pangan adalah segala sesuatu yang berasal dari sumber hayati produk pertanian, perkebunan, kehutanan, perikanan, peternakan, perairan, dan air, baik yang diolah maupun tidak diolah yang diperuntukkan sebagai makanan atau minuman bagikonsumsi manusia, termasuk bahan tambahan Pangan, bahan baku Pangan, dan bahan lainnya yang digunakan dalam proses penyiapan, pengolahan, dan/atau pembuatan makanan atau minuman.

2. Kedaulatan Pangan adalah hak negara dan bangsa yang secara mandiri menentukan kebijakan Pangan yang menjamin hak atas Pangan bagi rakyat dan yang memberikan hak bagi masyarakat untuk menentukan sistem Pangan yang sesuai dengan potensi sumber daya lokal.

3. Kemandirian Pangan adalah kemampuan negara dan bangsa dalam memproduksi Pangan yang beraneka ragam dari dalam negeri yang dapat menjamin pemenuhan kebutuhan Pangan yang cukup sampai di tingkat perseorangan dengan memanfaatkan potensi sumber daya alam, manusia, sosial, ekonomi, dan kearifan lokal secara bermartabat.

4. Ketahanan Pangan adalah kondisi terpenuhinya Pangan bagi negara sampai dengan perseorangan, yang tercermin dari tersedianya Pangan yang cukup, baik jumlah maupun mutunya, aman, beragam, bergizi, merata, dan terjangkau serta tidak bertentangan dengan agama, keyakinan, dan budaya masyarakat, untuk dapat hidup sehat, aktif, dan produktif secara berkelanjutan.

5. Keamanan Pangan adalah kondisi dan upaya yang diperlukan untuk mencegah Pangan dari kemungkinan cemaran biologis, kimia, dan 
benda lain yang dapat mengganggu, merugikan, dan membahayakan kesehatan manusia serta tidak bertentangan dengan agama, keyakinan, dan budaya masyarakat sehingga aman untuk dikonsumsi.

6. Produksi Pangan adalah kegiatan atau prosesmenghasilkan, menyiapkan, mengolah, membuat, mengawetkan, mengemas, mengemas kembali, dan/atau mengubah bentuk Pangan.

Menurut Suharingsih (2013:480) dari pengertian diatas menunjukkan bahwa semuanya satu kesatuan yang saling melengkapi dan memberi makna kuat, tertanam dalam pemikiran setiap orang antara ketahanan pangan dan kedaulatan pangan merupakan dua keadaan yang diperlukan agar kesejahteraan rakyat terwujud. Lima komponen penting yang harus ada yaitu: (a) komponen kebijakan dari pemerintah untuk mengusahakan hak atas tanah terpenuhi, (b) komponen sumber pangan yang tersedia di daerah perlu digali terus, (c) komponen lahan petani, tempat menanm tanaman pangan, (d) komponen petani, sebagai penyedia pangan, (e) keempat komponen tersebut harus disiapkan dan dikondisikan dengan niat.

Dalam hal perlindungan komoditas tanaman pangan dalam negeri pemerintah juga telah membuat Undang-Undang No 19 Tahun 2013 Tentang Perlindungan dan Pemberdayaan Petani yang merupakan sebuah usaha untuk memberikan perlindungan serta semangat pemberdayaan petani.

Dalam tataran normatif memang sudah diatur oleh pemerintah, akan tetapi dalam tataran praktisnya boleh kita lihat pada sebuah tabel nilai tukar petani pada tahun 2013 hasil olahan data badan pusat statistik (BPS) yang diposting oleh Kadir Ruslan (2013) sebagai berikut.

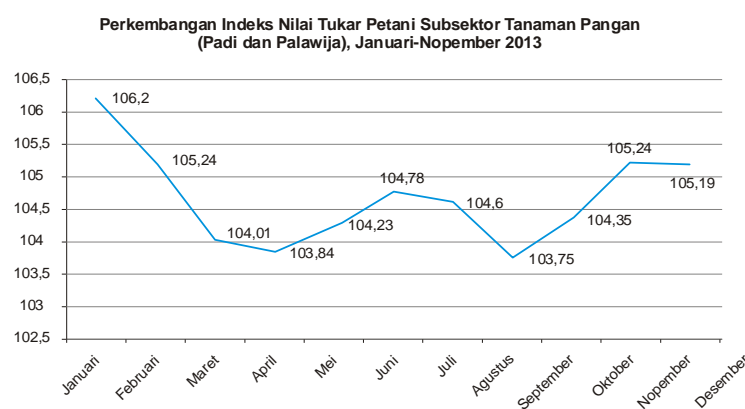

Seperti diketahui, perkembangan NTP merupakan indikator yang kerap digunakan untuk melihat perkembangan tingkat kesejahteraan petani. Kenaikan nilai NTP menunjukkan perbaikan tingkat kesejahteraan petani, begitupula sebaliknya. Sepanjang periode Januari hingga April 2013, nilai NTP bahkan terus mengalami penurunan secara konsisten. Itu artinya, tingkat kesejahteraan petani terus memburuk meski pada saat panen raya, di saat produksi berlimpah. Ini mengkonfirmasi, pembangunan pertanian selama ini terlalu dititikberatkan pada peningkatan produksi secara aggregate dan cenderung abai terhadap peningkatan kesejahteraan petani. Dengan tak kunjung dilaksanakannya reforma agraria sebagaimana yang dijanjikan, pemerintah seolah menutup mata bahwa peningkatan produksi yang terjadi sejatinya merupakan hasil perjuangan dan jerih payah para petani kecil.

Berbagai macam permasalahan empiristik dilapangan terkait perjalanan bangsa ini menuju ketahanan pangan nasional, makin terasa kompleks pasca Indonesia meratifikasi Asean Charter yang dalam bentuk UU No 38 Tahun 2008.Hal ini dibuktikan dengan diajukannya gugatan Pengujian UU No 38 Tahun $2008 \mathrm{Ke}$ Mahkamah Konstitusi oleh berbagai macam NGO serta organisasi kemasyarakatn petani karena berbagai macam hal kemudian dirasakan merugikan hak kosntitusional para pemohon khususnya petani Indonesia (2013:484).

Belum lagi masalah Beberapa kebijakan perdagangan dalam era globalisasi ternyata mengesampingkan kepentingan petani nasional. Padahal, sebagai salah satu sektor pembangun perekonomian nasional, hasil bercocok tanam petani juga menentukan keberhasilan program pemerintah dalam swasembada pangan. Liberalisasi perdagangan akan mempermudah masuknya produk impor ke Indonesia melalui beberapa perjanjian dan kerjasama antar negara. Sebut saja ASEAN-China Free Trade Area (ACFTA) dan ASEAN Economic Community yang akan beroperasi mulai 2015. Implementasi kedua perjanjian ini diyakini bisa mematikan produksi dalam negeri. Pasar domestik dibanjiri oleh produk asing yang harganya jauh lebih murah ketimbang produk pangan yang dihasilkan petani Tanah Air. Bahkan dari perjanjian tersebut, semua produk dari negara yang tergabung di dalam ACFTA dan AEC dibebaskan bea masuk dan tarif.

Kesejahteraan kaum tani dan organisasi kaum tani tidak lepas dari perkembangan di lingkungan sekitarnya, mulai dari kampung, dusun, desa, kota/ 
kabupaten, hingga nasional dan internasional, baik dari segi sosial ekonomi, budaya maupun politik. Karenanya seiring dengan perkembangan informasi, teknologi dan penerapan demokrasi, petani tidak hanya memantau lintang waktu untuk musim tanam padinya, namun mau tidak mau juga harus memantau apa yang terjadi di balai desa, pendopo bupati, kantor kementrian pertanian, istana negara dan bahkan kantor pusat Bank Dunia, IMF, WTO, FAO dan IFAD. Dua badan terakhir ini merupakan lembaga Internasional di bawah PBB yang mengurus pangan, pertanian dan pembiayaan pembangunan pertanian Internasional. Lebih dari itu FAO dan IFAD sudah sekian lama menjalin kerjsa sama dengan Pemerintah Indonesia untuk program-program pembangunan pertanian di Indonesia.

Dalam tiga tahun terakhir situasi pangan dan pertanian internasional dapat dikatakan tidak stabil, oleh karena terpaan krisis keuangan global, krisis energi dan krisis perubahan iklim. Terpaan tersebut menghasilkan dampak kemiskinan dan kelaparan. Khususnya di kawasan pedesaan. Laporan FAO (2010) menyebutkan bahwa kelaparan penduduk dunia tahun 2009 mencapai 1.02 milyar, sementara kelaparan di Indonesia dilaporkan berjumlah 36.7 juta. Hal ini dapat diartikan bahwa ada persoalan yang sangat serius dalam akses terhadap alat produksi, mode produksi, distribusi dan pasar, sehingga buruh tani dan petani kecil di pedesaan menjadi miskin dan lapar karena termarginalkan dalam sistem pembangunan pertanian yang tidak adil.

Forum Petani Nasional dalam rangka refleksi menuju konsolidasi petani seluruh Indonesia. Forum ini dihadiri oleh 13 organisasi petani seluruh Indonesia yang menyimpulkan bahwa, ada sembilan masalah pokok yang dihadapi oleh petani di Indonesia, yaitu: (a) kepemilikan lahan yang dimilki petani sangat sempit, rata-rata 0,3 Hetar per Rumah Tangga Petani, (b) akses air yang sulit, selain karena kekeringan yang semakin sering terjadi juga karena privatisasi sumber-sumber air oleh pemilik modal, (c) kebijakan perbenihan nasional yang diskriminatif terhadap kreatifitas petani pemilia benih, (d) belum ada jaminan perlindungan harga yang adil bagi di tingkat petani, sehingga pasar dimonopoli oleh pemodal besar dan korporasi pertanian, (e) sulitnya akses permodalan untuk petani di pedesaan, sehingga banyak petani yang tergantung pada tengkulak atau rentenir, (f) lemahnya dukungan pemerintah dalam mendukung infrastruktur pertanian (irigasi, jalan, teknologi tepat guna) dan saprodi kepada petani, (g) terjadi ledakan hama yang sulit dikendalikan oleh petani, karena iklim yang ekstrim, sehingga masa tanam ke-2 banyak petani gagal panen, (h) masih tingginya ketergantungan petani terhadap pupuk dan pestisida kimia akibat revolusi hijau di masa lalu, dan (i) rendahnya keterlibatan organisasi tani terhadap perencanaan, kebijakan dan pembangunan pertanian di Indonesia

Dari sebuah perbandingan antara kondisi riil dilapangan dan pada tataran normatif yaitu berupa peraturan perundang-undangan, maka banyak terjadi sebuah pengingkaran terhadap produkproduk dalam negeri kita. Politik hukum tentang pangan nampaknya sudah jauh masuk kedalam tataran ekonomi liberal. Ini secara langsung akan berdampak pada krisis pangan nasional dan juga akan berdampak kerusakan lingkungan.

\section{REKONSTRUKSI POLITIK HUKUM PERLINDUNGAN TANAMAN KOMODI- TAS PANGAN DALAM NEGERI GUNA MEWUJUDKAN KEDAULATAN PANGAN NASIONAL}

Indonesia hari ini boleh dikatakan telah melakukan kebijakan ekonomi terbuka. Oleh karena itu, perubahan harga pangan di tingkat domestik juga tidak dapat terpisahkan dari pengaruh harga pangan pada tingkat global. Oleh karena itu tidak heran jika harga komoditas pangan selama kurang lebih dua puluh tahun terakhir cenderung mengalami peningkatan. Hal ini juga merupakan tantangan tersendiri bagi Indonesia karena fluktuasi harga pangan di tingkat domestik menunjukkan kecenderungan yang lebih tinggi dibandingkan rata-rata kenaikan global.

Konstruksi baru politik hukum perlindungan komoditas pangan dirumuskan dengan cara melakukan penelusuran terhadap konstruksi ideal dan exiting dari politik hukum. Jadi antara undangundang perlindungan komoditas pangan dalam negeri dan institusi pelaksana ini dapat berdialektika untuk mencapai sebuah tujuan bersama.

Negara mempunyai kewajiban untuk mewujudkan kedaulatan pangan dalam negeri. Sehingga negara dapat melaksanakan peranan pentingnya dalam hal menekan atau meminimalisir suatu barang impor yang masuk ke wilayah Indonesia. Negara mempunyai kewenanganuntuk 
mengatur dengan cara yang sesuai dengan kesepakatan international, masuknya tanaman dan hasil tanaman serta bahan lain harus sesuai dengan aturan, mengikuti ketentuan berikut.

a. Negara update database produk pangan dalam negeri, untuk mengetahui potensi dan masalah yang ada dalam pemenuhan kebutuhan pangan dalam negeri.

b. Negara memfiltrasi dalam hubungan pemasukan tanaman, produk tanaman atau bahan lain yang masih bisa dipenuhi sendiri oleh sistem pertanian nasional

c. Negara harus menolak terhadap bahan tanaman impor yang bisa merugikan petani lokal.

Untuk mengatasi kegagalan pasar (market failure) seperti monopoli dan eksternalitas yang merugikan, maka peran pemerintah sangat diperlukan dalam perekonomian suatu negara. Peranan ini dapat dilakukan dalam bentuk intervensi secara langsung maupun tidak langsung. Berikut adalah intervensi pemerintah secara langsung dan tidak langsung dalam hal kebutuhan pangan,

\section{INTERVENSI PEMERINTAH SECARA LANGSUNG}

Berkaitan dengan intervensi pemerintah secara langsung yang digunakan untuk melindungi petani lokal dan konsumen. Petama, dalam hal perlindungan terhadap petani lokal makapemerintah melakukan penetapan harga minimum atau harga dasar produk kebutuhan pangan. Kedua, sebagai upaya pemerintah dalam melindungi konsumen mska pemerintah menetapkan harga maksimum atau Harga Eceran Tertinggi (HET) agar sesuai dengan daya beli masyarakat (konsumen). Penjual tidak diperbolehkan menetapkan harga diatas harga maksimum tersebut.

\section{INTERVENSI PEMERINTAH SECARA TIDAK LANGSUNG}

Kebijakan penetapan pajak dilakukan oleh pemerintah dengan cara mengenakan pajak yang berbeda-beda untuk berbagai komoditas. Artinya komoditas luar negeri harus dikenakan pajak lebih tinggi dari pada produk lokal, dan jangan sebaliknya. Sehingga konsumen lebih memilih untuk membeli hasil produk lokal.
Berbagai macam tantangan untuk dapat memenuhi permintaan pangan, bukan hanya berasal dari kelangkaan pangan, akan tetapi juga juga ada faktor lain yang disebabkan karena kurang meratanya distribusi pangan.Untuk mencapai pembangunan berkelanjutan, harus mengembangkan gagasan untuk membuat strategi yang dapat mengintegrasikan aspek-aspek kebijakan pertanian dan produksi pangan, serta pemanfaatan sumber daya alam yang berkelanjutan.

Memandang pentingnya pencapaian ketahanan dan kedaulatan pangan nasional, maka Dewan Perwakilan Rakyat Republik Indonesia(DPR RI) pada bulan Oktober 2012 mensahkan Undang Undang 18 tahun 2012 tentang pangan yang menggantikan Undang Undang No. 7 tahun 1996. Undang-Undang tersebut memberikan media berupa mekanisme menuju swa-sembada pangan dan menekankan pentingnya kedaulatan pangan nasional. Undang Undang Pangan yang baru tersebut juga berfungsi sebagai dasar hukum yang memadai dalam upaya mengatur, perencanaan, ketersediaan, harga komoditas, nutrisi dan konsumsi, keamanan, periklanan, pemberian label pada produk, dan institusipangan serta partisipasi publik dan pengimplementasian kebijakan.Upaya reformasi kebijakan pertanahan dan agraria juga telah menjadi salah satu agenda utama dalam pengembangan sektor pertanian di Indonesia sejak tahun 1960an. Pada tahun 2009, DPR RI telah mensahkan Undang Undang No. 41 tahun 2009 tentang Perlindungan Lahan Pertanian Pangan Berkelanjutan.

Undang Undang Pangan tersebut juga mengamantakan sebagai upaya adanya tanggung jawab bersama antara pemerintah pusat dengan pemerintah daerah dalam menjamin ketersediaan pangan nasional. Saat ini, ada tiga lembaga pangan di Indonesia, yaitu Dewan Ketahanan Pangan (DKP) yang diketuai oleh Presiden, Badan Ketahanan Pangan (BKP) di bawah Kementerian Pertanian, dan Perum BULOG.

Perlu ditekankan bahwa ketersediaan pangan bukan hanya merupakan persoalan sosialekonomi belaka, akan tetapi lebih jauh lagi adalah mengenai keamanan nasional. Selain itu Indonesia juga harus lebih mandiri dalam memastikan ketersediaan pangan dan mencapai ketahanan pangan. Sehingga pangan tidak boleh dipandang semata-mata sebagai komoditas politik atau 
komoditas bisnis, tetapi akses terhadap kecukupan pangan merupakan hak mendasar bagi seluruh manusia di dunia, lebih khusus adalah rakyat Indonesia itu sendiri.

Dari beberapa gagasan dan stratgei singkat di atas harapan penulis adalah terlakasananya sila kelima yakni "keadilan sosial bagi seluruh rakyat Indonesia". Karena ketika terlaksananya sila tersebut berarti telah terpenuhinya kebutuhan dasar dari rakyat yakni kebutuhan akan pangan.

\section{SIMPULAN}

1. Dari sebuah perbandingan antara kondisi riil dilapangan dan pada tataran normatif yaitu berupa peraturan perundang-undangan, maka

\section{DAFTAR RUJUKAN}

Sari, Amanda Puspita. 2014. Rincian Impor Beras di Indonesia 2013-2014. CNN Indonesia. Online (http:// www.cnnindonesia.com/ekonomi/ 20140809160536-92-1344/ini-rincianimpor-beras-di-indonesia-2013-2014/).

Erwin, Muhammad. 2013. Filsafat Hukum. Jakarta:Rajawali Pers.

Hadjon, M, Philiphus. 1987. Perlindungan hukum bagi rakyat Indonesia. Surabaya: Bina Ilmu.

Kurniawan, Iwan. 2012.Pemerintah mengimpor singkong sejak tahun 2007. Viva.co.id. 2012. (http:// bisnis.news.viva.co.id/news/read/375029pemerintah-akui-impor-singkong-sejak2007).

Komite IV Dewan Perwakilan Rakyat Daerah Republik Indonesia. 2014.Kebijakan Pembangunan Nasional dan Daerah. Jakarta.

Mahfud MD. 1998. Politik Hukum Indonesia. LP3S:Jakarta. banyak terjadi sebuah pengingkaran terhadap produk-produk dalam negeri kita. Politik hukum tentang pangan nampaknya sudah jauh masuk kedalam tataran ekonomi liberal. Ini secara langsung akan berdampak pada krisis pangan nasional.

2. Konstruksi baru politik hukum perlindungan komoditas pangan dirumuskan dengan cara melakukan penelusuran terhadap konstruksi ideal dan exiting dari politik hukum. Negara mempunyai kewajiban untuk mewujudkan kedaulatan pangan dalam negeri. Sehingga negara dapat melaksanakan peranan pentingnya dalam hal menekan atau meminimalisir suatu barang impor yang masuk ke wilayah Indonesia

Nisa, Nurun. 2012. Politik Perdagangan Buah Impor Indonesia Tahun 2011-2012. Pusat Studi Perdagangan Dunia Universitas Gajah Mada. (http://cwts.ugm.ac.id/ politik-perdagangan-buah-impor-indonesiatahun-2011-2012/)

Prasojo, Husdi. 2010. Setengah Abad Pengingkaran UUPA. (www.spi.or.id/ $? \mathrm{p}=2813$ ).

Safa' at, Rachmad. 2011. Rekonstruksi Politik Hukum Pangan. Malang:UB Press.

Raharjo, Satjipto. 2009. Hukum dan Perilaku.Kompas media nusantara: Jakarta.

Ruslan, Kadir. 2013.Dibalik Swasembada Pangan2013, (http://bitra.or.id/2012/2013/ 12/26/dibalik-swasembada-beras-tahun2013/).

Suhariningsih. 2014.Menuju "Ketahanan Pangan Nasional" berbasisi pada penguatan pemberdayaan petani. Bagian buku yang berjudul Liber Amicorum 70 Tahun Prof. Dr. Achmad Sodiki, SH.) 